can assure him that, while magistrate at Point Pedro, five-and. twe ty years ago, I used almost nightly to cee "rayons de crépu-cule" in the most glorious perfection for months together. Puint Pedro is the extreme northern point of the island, with a plendid sea horizon. I shall never forget the beauty of the tints. E. L. LAYARD

British Consulate, Nonmea, New Caledonia, February I

\section{Salmon in Rivers of the Pacific Slope}

IN a notice of the Report of the U.S. Commissioner of Fish and Fisheries, in NATURE, vol. xix. p. 430, the reviewer refers to the statement in a "memorandum respecting the American salmon and white fish recently introduced in New Zealand by Dr. Janes Hector," that "so far as yet observed, the adult fish all die after.spawning and never return to the sea." The reviewer writes: "We shall be glad to have some authoritative statement with regard to the above fact, as without some explanation it seems too extraordinary for belief."

Dr. Hector in the above remark refers to the so-called " $\mathrm{Cali}$ fornian Salmon" (Salmo quinnat) when in its native waters. There must be some exceptions to the rule as above stated, for Mr. Livingstone Stone, in his evidence in the same volume (p. 8o6), testifies that in the Columbia full-grown fish of this species are caught in considerable numbers, nearly exhatusted, on the back of the drift-nets, in July and August, but it is nevertheless almost strictly true.

In the Fraser River, British Columbia, the general opinion is that the salmon never return to the sea except accidentally in a dying state. The Indians, who are generally well informed on such points, affirm this. The late J. IK. Lorrl, in his "Naturalist in British Columbia," (vol. i. p. 40, et seq.), is very clear on the same point. It is, moreover, almost certain from the tumultuously rapid character of the Fraser, that the salmon hached in its upper waters-in some instances 600 miles from the sea-never return there till mature and ready to spawn, and that this act is their last. They show no disposition to attempt to so back to the sea. I have seen them in great numbers in small streams tributary to the North Thompson, in August, spent, their silvery colour turned to a livid red (with the exception of the fins and tail, which are darker) but still heading persistently up stream, and continuing to do so, till from sheer weakness the current carried them away. In fording the brooks, the disturbarice of the water causes those possessing sufficient vitality to scatter in all directions, but interrupts only for a moment their nosyed struggle. At this season, in most years, dead salmon in grat numbers are found floating down the stream, or stranded on the bars and banks of the river.

In Okanagan, Shuswap, and other lakes, there is a smaller r. $h$, which may be a "land-locked" salmon, but of which I was int able to preserve specimens. The Indians say that it does not come from the sea, but lives in the deep waters of the lake, liil in August it enters certain streams to spawn. Like the saliann it becomes, when spent, first blotched with pale red, and eventually altogether of that colour and without silvery lustre, the flesh at the same time losing its pink tint. It possesses the same instinct of struggling against the stream till it dies. I have seen them in brooks within a stone's throw of the lake, endeavouring with their remaining strength to keep themselves from being carried back into it.

ford makes an exception of the "fall" or "dog-tooth" calmon $(S$. lycaodon), of which he supposes some go back to the sea, and return to the rivers in following years. It remains, however, an undoubted fact, that by far the greater part of the prodisious number of salmon entering the Fraser every year, perish. The fish appears to refuse food, and is not caught in the river by bait or fly, though frequently taken by trolling with fish or spoon-bait in the salt water.

It is much to be desired that a systematic investigation of the species of salmon frequenting the Fraser and other rivers of British Columbia should be made, embracing their habits and the course of their migrations. The subject is an interesting, but very intricate one. GEORGE M. DAWSON

Geological Survey of Canada, Montreal, March 27

\section{The Marsupials of Australia}

THE peculiarities of the structure of the marsupials of Ans. tralia are so remarkable and their habits are so unlike those of the placentals of the Old World, that probably no apology is teeded for venturing to lay before your readers a short account of one of these peculiarities possessed by certain genera, which I believe has escaped the observation of most naturalists, and may prove interesting to some of your subscribers.

The inferior maxillary or lower jaw-bone of almost all known mammals consists of two bones united together with more or less rigidity by a strong cartilage, which allows no play or independent movement whatever, and which practically firmly unites them into one bone.

The formation of the inferior maxillary of the Macropidæ, or kangaroos, is an exception, however, to this rule; instead of being united by a cartilage, the two rami of the lower jaw are jointed at their point of contact with a hinge somewhat resembling that upon which the two shells of a bivalve move, that is, upon corrugations which project from the two edges and fit accurately into one another.

These two rami extend a short distance beyond the point of contact, and into their terminations are fixed two long procum. bent incisor teeth, the only two incisors possessed by this family in the lower jaw. Immediately in front of this joint, that is, at the root of the procumbent incisors, a circular muscle embraces the two rami of the jaw, the contraction of which has the effect of bringing the inner edges of the procumbent teeth together; upon its relaxation or the contraction of another set of muscles, placed probably at the extremities of the rami, where they hinge upon the facial bones, the incisors are separated the extreme distance allowed them by the ligaments around the joint. The action of separating the teeth is probably connected in some measure with the action of opening the jaws, as I not unfre. quently found that when the mouth was widely opened, the teeth themselves became separated.

The muscular action of uniting the incisors may be said to be exemplified in the case of a pair of shears when the blades are closed by a grasp of the hand, and the force is applied between the fulcrum and the point of resistance.

In Prof. Owen's work upon the "Anatomy of the Vertebrates," the following passage appears, showing that he was aware of a certain looseness of connection of the two rami, but probably not aware of the completeness of the construction with its separate functions. After certain references to the wombat he says, "In other marsupials the rami of the lower jaw are less firmly united at the symphysis; they permit independent movements of the right and left incisors in the kangaroos, and in the opossum both the rami of the lower jaw and all the bones of the face are remarkable for the loose nature of their connections,"

In the work upon "Odontography" sy the same distinguished writer, various references are made to the lower incisors of the macropidæ, but his readers are in every instance led to believe that their trenchant margin is their outer edge, and I believe it has escaped his observation altogethei, that the inner margin where the two teeth come in contact has the principal cutting edge.

Mr. G. R. Waterhouse was aware of the inner trenchant margin as in his "Natural History of the Mammalia," he refers to these incisors as having "cutting external and internal margins." Further on he says- "In Macropus major (and, perhaps, in some nearly allied species), the rami of the lower jaw are loosely attached at the chin, and at the apex they are free, and the animal has the power of slightly separating the lower incisors, so that their outer cutting edges are brought more closely in contact with the upper incisors than they otherwise would be." Were this, however, the only utility of the loose attachment at the symphysis, what function has the cutting inner margin to perform?

An examination of those incisors will disclose the following facts :-

If the jaw of one of the macropidæ is examined immediately after death, when the muscles are relaxed, it is found that the smallest pressure upon the base of the rami suffices to open the lower incisors to the extent of about one.fourth of an inch in larger specimens, and about one-eighth in the smaller Pademelons or Halmaturi. The inner edyes of the procumbent teeth will then be seen to be sharp, but strongly supported by a considerable thickness of enamel immediately in rear of the edge, and when the teeth are united by the contraction of the muscles, they fit so perfectly throughout their whole length that they will grasp a hair at any point between the base and the apex. On the other hand; the outer margins of these teeth are blunt and somewhat rounded, and when the jaw is closed and at rest, instead of fitting on to the teeth of the upper jaw, as represented in diagrams in Owen's "Odontography," the 